\title{
Detection of nodavirus in seawater from rearing facilities for Atlantic halibut Hippoglossus hippoglossus larvae
}

\author{
Audun H. Nerland ${ }^{1, *}$, Cecilie Skaar ${ }^{1}$, Tove Boge Eriksen ${ }^{1}$, Hogne Bleie ${ }^{2}$ \\ ${ }^{1}$ Institute of Marine Research, PO Box 1870 Nordnes, 5817 Bergen, Norway \\ ${ }^{2}$ National Veterinary Institute, PO Box 1263 Sentrum, 5811 Bergen, Norway
}

\begin{abstract}
We used (1) ultracentrifugation followed by RT-PCR and (2) real-time RT-PCR to detect and quantify nodaviruses in seawater in which Atlantic halibut Hippoglossus hippoglossus larvae/fry had been held at rearing facilities. Evaluated against in vitro propagated viruses, the viral concentration corresponded to $1.6 \times 10^{4} \mathrm{TCID}_{50}\left(50 \%\right.$ tissue culture infectious dose) $\mathrm{ml}^{-1}$. Evaluated against in vitro transcribed RNA, the concentration was estimated at $2 \times 10^{7}$ virus particles $\mathrm{ml}^{-1}$ seawater.
\end{abstract}

KEY WORDS: Nodavirus · RT-PCR · Real-time PCR · Quantification · Seawater · Atlantic halibut

\section{INTRODUCTION}

The complex life cycle of the Atlantic halibut Hippoglossus hippoglossus L. and the delicate nature of its eggs and yolk-sac larvae call for specialized facilities with a stable environment for the successful rearing of this species. After stripping, fertilization, and incubation, the eggs are transported to sites with large seawater silos, in which the larvae are hatched and held during the yolk-sac stage. When they are ready for first feeding on live prey, the larvae are moved locally for either intensive rearing in landbased tanks or extensive rearing in floating bags in marine lagoons. Intensive rearing of halibut larvae is currently based exclusively on a diet of nutrientenriched live brine shrimp Artemia salina, while, in extensive rearing, the larvae are offered live zooplankton collected from the surrounding seawater, with or without a supplement of brine shrimp. After a period of pelagic existence, the larvae metamorphose into bottom-living juveniles, and the 'weaning' process of adjusting the juveniles to an inert diet takes place. At this stage, the juvenile halibut are usually moved to tanks before further growth in specialized sea cages or in large land-based tanks.
At present, one of the greatest obstacles to successful Atlantic halibut culture in Norway is the recurring mass mortality of halibut larvae and juveniles associated with vacuolated lesions in central nervous system tissue (Grotmol et al. 1997). These histopathological changes have been shown to be due to nodavirus infections (Grotmol et al. 1999), and the disease called VER (viral encephalopathy and retinopathy) or VNN (viral nervous necrosis). Nodaviruses are known to cause severe disease in a wide range of marine fish in different parts of the world (Munday \& Nakai 1997, Munday et al. 2002). Nodaviruses are amongst the smallest viruses known, and they consist of an icosahedral capsid 25 to $35 \mathrm{~nm}$ in diameter containing 2 single-stranded RNA molecules: RNA1 (3100 nt) and RNA2 (1400 nt). The epidemiology of nodavirusrelated disease in marine fish is not fully understood. However, both vertical (Arimoto et al. 1992, Mushiake et al. 1994) and horizontal transmission of nodaviruses (Munday \& Nakai 1997) have been demonstrated in striped jack Pseudocaranx dentex. Experimental vertical transmission of nodavirus from broodfish to eggs and larvae of sea bass Dicentrarchus labrax was shown by Breuil et al. (2002). In Atlantic halibut, vertical susceptibility of yolk-sac larvae to waterborne 
nodaviruses has been experimentally demonstrated (Grotmol et al. 1999), and the occurrence of vertical transmission in nature has been indicated (Grotmol \& Totland 2000). The present study reports the detection of high concentrations of nodavirus in rearing units where infected Atlantic halibut larvae have been held, indicating the likelihood of horizontal transmission of the virus between halibut larvae/fry.

\section{MATERIALS AND METHODS}

Virus sources and samplings. The nodavirus strain AHNV692/9/98, isolated in Norway and propagated in the striped snakehead cell line SSN-1, was a gift from the National Veterinary Institute, Oslo (Dannevig et al. 2000). The titer of the virus was calculated to be $10^{8}$ TCID $_{50} \mathrm{ml}^{-1}$ according to the procedure of Reed \& Muench (1938).

Seawater samples and larvae were collected from 2 commercial Atlantic halibut Hippoglossus hippoglossus hatcheries that had confirmed a nodavirus disease problem. At one of the hatcheries, the water samples were taken from 3 different $75 \mathrm{~m}^{3}$ floating bags situated in a marine lagoon. Each of the bags contained around 40000 larvae (size: $100 \mathrm{mg}$ ). The samples were taken at a depth of $2 \mathrm{~m}$ in the $4 \mathrm{~m}$ deep bags in July when the ambient temperature ranges from 10 to $15^{\circ} \mathrm{C}$. At this hatchery, water samples were also collected at the site of zooplankton collection. At the other hatchery, the water samples were taken from a $25 \mathrm{~m}^{3}$ land-based weaning tank containing around 5000 larvae (size: $400 \mathrm{mg}$ ). At this second hatchery, water samples were taken from the inlet water supply, which came from a sea depth of $70 \mathrm{~m}$ about $500 \mathrm{~m}$ off the coast, where the water temperature was about $10^{\circ} \mathrm{C}$. The samples from each site were taken at least in duplicate. All samples were stored at $-20^{\circ} \mathrm{C}$ until analysis.

Ultracentrifugation and RT-PCR of seawater. The virus particles were concentrated from $11 \mathrm{ml}$ of seawater by ultracentrifugation at $200000 \times g$ for $60 \mathrm{~min}$. The pellet was resuspended in $200 \mu \mathrm{H}_{2} \mathrm{O}$, and the RNA was isolated by the High Pure Viral Nucleic Acid kit (Roche) according to the protocol provided by the manufacturer. The RNA was dissolved in $50 \mu$ l RNasefree water. From this suspension, $1 \mu$ l was transferred to $9 \mu \mathrm{l}$ of RT-reaction mix for a reverse transcriptase reaction, followed by PCR as described previously (Grotmol et al. 2000); the primers employed, Ah95-F1 (5'-AGTGCTGTGTCGCTGGAGTG-3') and Ah95-R1 (5'-CGCCCTGTGTGAATGTTTTG-3'), generate a PCR fragment of $341 \mathrm{bp}$ corresponding to the region 593 to $934 \mathrm{bp}$ downstream from the start codon of RNA2. Sample buffer $(50 \mathrm{ml})$ was added to $7 \mu \mathrm{l}$ of the PCR product, and the mixture was run on a $2 \%$ agarose gel in Tris-borate-EDTA (TBE) buffer using standard methods (Sambrook et al.1989). DNA visualized by ethidium bromide staining was photographed using the Gel Doc 2000 gel documentation system (BIO-RAD). The intensities of the bands were compared using Quantity One software from BIO-RAD. A positive control (based on a standard amount of in vitro propagated nodavirus) and a negative control (minus template) were also applied on the gel.

To evaluate the sensitivity of the method in vitro propagated viruses were diluted in seawater. Samples of $10^{-3}, 10^{-4}, 10^{-5}, 10^{-6}$, and $10^{-7}$ dilutions of the virus stock $\left(10^{8} \mathrm{TCID}_{50} \mathrm{ml}^{-1}\right)$ were centrifuged and further treated and analyzed as described above.

Real-time RT-PCR. RNA was isolated from samples of $100 \mu \mathrm{l}$ seawater or viral suspension using the RNeasy Mini kit (Qiagen) and was eluted in $50 \mu \mathrm{l}$ RNase-free water. Then, $10 \mu \mathrm{l}$ of isolated RNA was mixed with $1 \mu$ of $50 \mu \mathrm{M}$ random hexanucleotides, heated to $70^{\circ} \mathrm{C}$ for $5 \mathrm{~min}$, cooled on ice, and $1 \times \mathrm{PCR}$ buffer (Applied Biosystems), $5 \mathrm{mM} \mathrm{MgCl}_{2}, 1 \mathrm{mM}$ dNTP, 1 U RNase inhibitor, and $5 \mathrm{U}$ MuLV reverse transcriptase in a total volume of $20 \mu \mathrm{l}$ were added. The mixture was incubated at $42^{\circ} \mathrm{C}$ for $1 \mathrm{~h}$. We then added $900 \mathrm{nM}$ forward primer AhRNA2tmF1 (5'-AATGGTGGGAAAGCAGAACAA-3'), 900 nM reverse primer AhRNA2tmR1 (5'-CCGAGGTCCAGA GGAGTGC-3'), 250 nM TaqMan probe AhRNA 2TagM (6-Fam-5'-CCGACCCCAGCATGCCCG-3' TAMRA), and $1 \times$ TaqMan Universal PCR master mix in a total volume of $50 \mu \mathrm{l}$ to $5 \mu \mathrm{l}$ of the resulting cDNA. This mixture was run on an ABI-Prism Model 7700 under the following reaction conditions: $2 \mathrm{~min}$ at $50^{\circ} \mathrm{C}$ and $10 \mathrm{~min}$ at $95^{\circ} \mathrm{C}$, followed by 40 cycles of $15 \mathrm{~s}$ at $95^{\circ} \mathrm{C}$ and $1 \mathrm{~min}$ at $60^{\circ} \mathrm{C}$. The primers used generate a PCR fragment of $60 \mathrm{bp}$ corresponding to the region 451 to $511 \mathrm{bp}$ downstream from the start codon of RNA2, and the probe binds to the middle of this PCR fragment. The data were analyzed using the computer program Sequence Detector Version 1.7 (Applied Biosystems).

To obtain an estimate of the titer corresponding to $\mathrm{TCID}_{50}, 10$-fold dilutions of in vitro propagated virus $\left(10^{7}\right.$ to $\left.10 \mathrm{TCID}_{50} \mathrm{ml}^{-1}\right)$ were used as standards. To estimate the actual number of RNA templates in vitro transcribed RNA templates were prepared as previously described by Grotmol et al. (2000). Briefly, the plasmid pAHT6, containing an insert corresponding to the T6 region of RNA2 cloned behind the T7 promoter, was used as template for T7 polymerase, and the RNA obtained was purified and then quantified by measuring the optical density at $260 \mathrm{~nm}$. Tenfold dilutions of RNA, ranging from $10^{9}$ to $10^{4}$ copies $\mathrm{ml}^{-1}$, were used as standards. 
Testing of larvae by RT-PCR. Testing for the presence of nodavirus was performed as described by Grotmol et al. (1999) using the primers Ah95-F1 and Ah95-R1 described above.

Histological and immunohistochemical techniques. These techniques were applied on formalin-fixed halibut larvae and fry as described by Grotmol et al. (1999).

\section{RESULTS}

\section{Detection by ultracentrifugation and RT-PCR}

The sensitivity of the method was tested by analyzing serial dilutions of in vitro propagated virus. Positive signals were observed in dilutions down to $10^{-5}$, corresponding to $1000 \mathrm{TCID}_{50} \mathrm{ml}^{-1}$ (Fig. 1, Lanes 1 to 5).

Positive signals were detected from seawater samples drawn from 3 different floating bags at the exten-

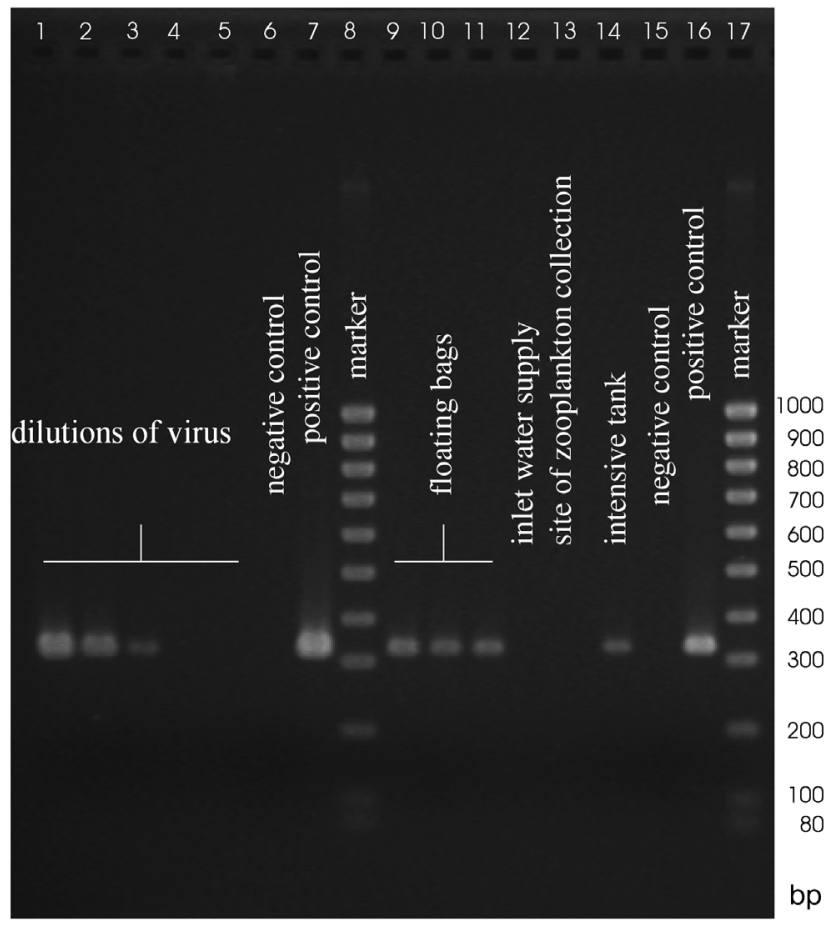

Fig. 1. Agarose gel electrophoresis of PCR products. The template cDNA was prepared from the following sources. Lanes 1 to 5 are in vitro propagated virus diluted in seawater $\left(10^{5}, 10^{4}\right.$, $10^{3}, 10^{2}$, and $10 \mathrm{TCID}_{50} \mathrm{ml}^{-1}$, respectively). Lanes 7 and 16 are positive controls (based on a standard amount of in vitro propagated nodavirus). Lanes 9 to 11 are water samples from 3 different floating bags (extensive production). Lane 12 is a water sample from the inlet water supply. Lane 13 is a water sample from the site of zooplankton collection. Lane 14 is a water sample from the tank where the weaning process takes place. Lanes 6 and 15 are negative controls (minus template), and Lanes 8 and 17 are markers (size of the fragments in base pairs given on the right) sive production unit (corresponding to Lanes 9, 10, and 11 in Fig. 1), and in a sample from the land-based tank for weaning to which Atlantic halibut Hippoglossus hippoglossus fry from a floating bag (extensive production) had been moved (corresponding to Lane 14 in Fig. 1).

By comparing the intensities of the signals produced by the samples from the hatchery with the signals obtained from samples of diluted virus particles, the concentrations of viruses in the feeding tanks were estimated to be from $10^{3}$ to $10^{5} \mathrm{TCID}_{50} \mathrm{ml}^{-1}$.

Water samples from the inlet water supply of the intensive production unit and from the site of zooplankton collection at the extensive production unit (corresponding to Lanes 12 and 13, respectively) produced no signals.

\section{Detection by real-time RT-PCR}

The sensitivity of the method was tested by using serial dilutions of in vitro propagated viruses or in vitro transcribed RNA. Sensitivities were found to be around $10 \mathrm{TCID}_{50}$ units $\mathrm{ml}^{-1}$ and $10^{4}$ copies $\mathrm{ml}^{-1}$ synthetic RNA, respectively, which correspond, in turn, to $0.05 \mathrm{TCID}_{50}$ or 50 copies of RNA per final amplification reaction.

Tenfold serial dilutions of a water sample from the floating bag, corresponding to Lane 10 in Fig. 1, were submitted to real-time RT-PCR. We detected positive signals down to 1000-fold dilution of the water (data not shown). For estimation of the virus concentration, an undiluted water sample was compared with 10-fold dilutions of in vitro propagated nodavirus, ranging from $10^{7}$ to $10^{1} \mathrm{TCID}_{50} \mathrm{ml}^{-1}$ (Fig. 2a). The virus concentration appeared to correspond to $1.6 \times 10^{4} \mathrm{TCID}_{50}$ $\mathrm{ml}^{-1}$. The undiluted water sample was also compared with 10-fold dilutions of in vitro transcribed RNA, ranging from $10^{9}$ to $10^{4}$ copies $\mathrm{ml}^{-1}$ (Fig. 2b), where the virus concentration in the seawater was estimated to correspond to $2 \times 10^{7}$ copies $\mathrm{ml}^{-1}$.

\section{Examination of the larvae}

In all the bags/tanks where the water samples were found to give positive signals, larvae/fry were found dead or dying with clinical symptoms resembling VER. From 1 of the floating bags (corresponding to Lane 10 in Fig. 1), 5 larvae were removed at the same time as the water sample was collected. These larvae were homogenized and analyzed by RT-PCR and found to be nodavirus positive (data not shown). Fry from the weaning tank (corresponding to Lane 14 in Fig. 1) were examined histologically. The histological picture 

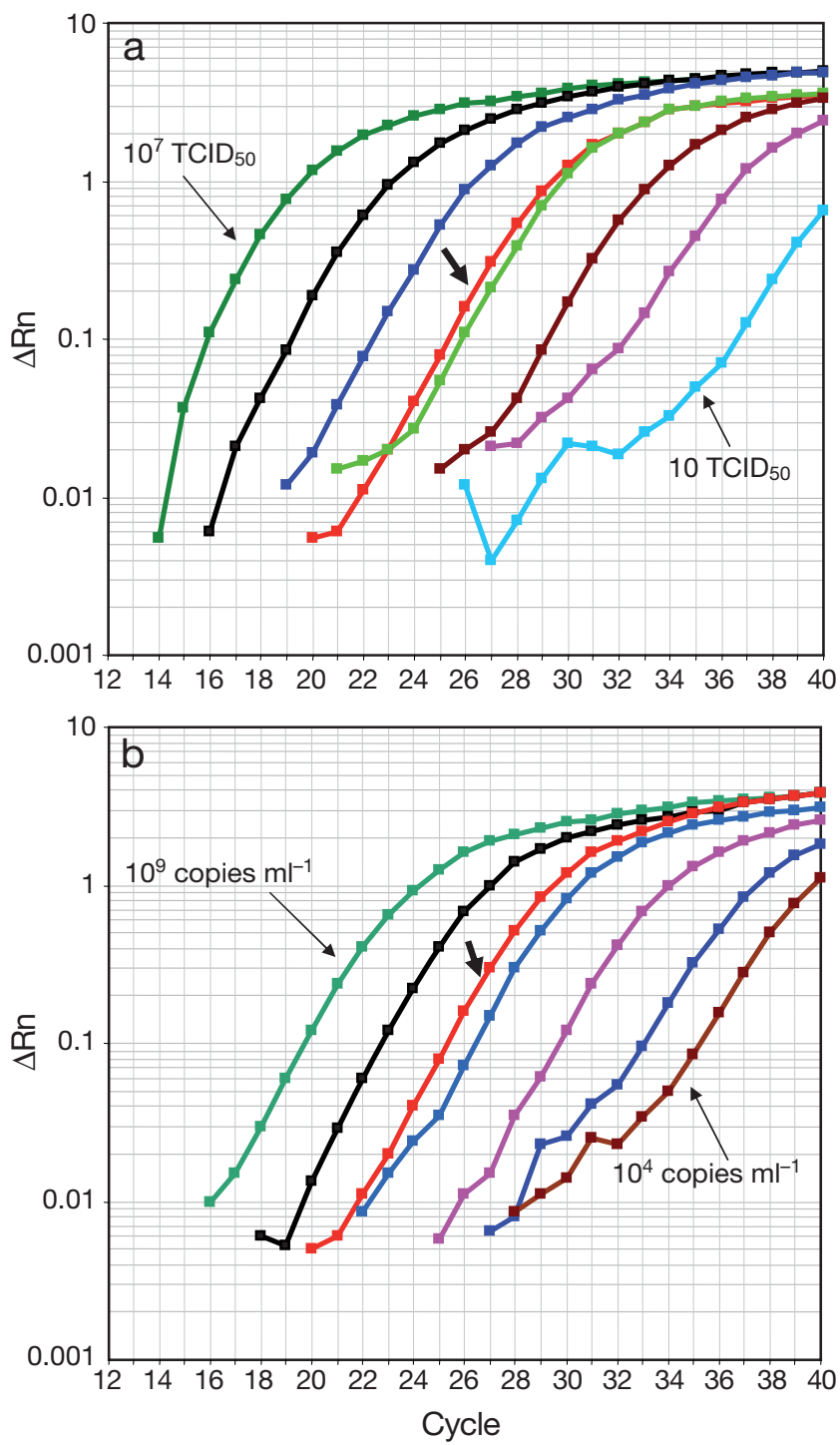

Fig. 2. Amplification plots showing the detection of nodavirus in seawater (red curve, bold arrow) compared to (a) samples prepared from 10-fold serial diluted nodavirus propagated in cell culture and (b) samples prepared from 10-fold serial diluted in vitro transcribed RNA2. $\Delta \mathrm{Rn}$ is a measurement of the change in fluorescent signal vs. a passive reference signal and 'cycle' refers to the rounds of amplification

revealed vacuoles typical of VER, and an immunohistological examination using antibodies against nodavirus gave positive signals, confirming that the fry were actually infected with VER.

\section{DISCUSSION}

We used 2 different methods to detect and quantify the concentration of nodavirus in seawater sampled from rearing units for larvae/fry of Atlantic halibut Hippoglossus hippoglossus.
In the first method, $11 \mathrm{ml}$ of seawater was subjected to ultracentrifugation, and RNA was isolated from the resulting pellet used as the starting material for standard RT-PCR. The sensitivity of the test was found to be around $1000 \mathrm{TCID}_{50} \mathrm{ml}^{-1}$. The virus concentration in the rearing units was estimated by this method to be between $10^{3}$ and $10^{5} \mathrm{TCID}_{50} \mathrm{ml}^{-1}$. However, quantification using this method is based on comparison of the intensity of bands on agarose gels, with the inherent limitations of this procedure.

In the second method, RNA isolated from $0.1 \mathrm{ml}$ of seawater was reverse transcribed and then subjected to real-time PCR. This method was more sensitive, enabling detection down to $10 \mathrm{TCID}_{50} \mathrm{ml}^{-1}$ using in vitro propagated virus as a standard. With this standard the concentration of nodavirus in the seawater was estimated to correspond to $1.6 \times 10^{4} \mathrm{TCID}_{50} \mathrm{ml}^{-1}$, which is within the range of the quantification made by the ultracentrifugation/RT-PCR method. This second methodology also made it possible to apply purified in vitro-transcribed RNA as a standard, so that the number of copies could be calculated by measuring the concentration with a spectrophotometer at $260 \mathrm{~nm}$. Using this standard, we found the method capable of detecting down to approximately $10^{4}$ copies $\mathrm{ml}^{-1}$ and we determined that the seawater contained $2 \times 10^{7}$ viruses $\mathrm{ml}^{-1}$. This means that $1 \mathrm{TCID}_{50}$ unit corresponds to approx. 1200 copies of RNA or to the number of viruses, which is in accordance with estimates made by others (Starkey et al. 2004).

Although the susceptibility of halibut larvae to waterborne nodavirus has been experimentally demonstrated by Grotmol et al. (1999), the concentration of virus in the suspension used for challenging was not determined in their study. However, Sommer et al. (2004) observed high mortality in $1 \mathrm{~g}$ wolffish Anarhichas minor larvae after bath challenge in nodavirus suspension containing approximately $10^{3}$ TCID $\mathrm{ml}^{-1}$, indicating that the concentration of virus detected in this study $\left(10^{4} \mathrm{TCID} \mathrm{ml}^{-1}\right)$ may be sufficiently high for horizontal transmission to take place.

To control nodavirus infections in aquaculture it is important to understand the epidemiology of the virus. In theory, the virus can be transmitted through the inlet water or the feed, or from the broodstock via the eggs/sperm. Although this study demonstrated a high concentration of virus in the environment around diseased larvae, the likelihood of acquiring infection through the inlet water is low (due to the enormous dilution of the seawater), unless infected fish are residing very close to the seawater pipeline inlet. Tests of inlet water and seawater at the site of zooplankton collection in our study did not detect virus (Fig. 1, Lanes 12 and 13). Rotifers and brine shrimp do not appear to be susceptible to nodavirus (Skliris \& Richards 1998), 
making the feed an unlikely transmission channel. On the other hand, vertical transmission from the broodstock has been demonstrated (Breuil et al. 2002). In addition, subclinical infections of nodavirus have also been reported, and the virus has been shown to still be infectious after $1 \mathrm{yr}$ (Johansen et al. 2004). It is therefore tempting to speculate that the major transmission route of nodavirus is from broodstock, where it can 'hide' in a subclinical state until some mechanism activates it at the time of maturation and spawning, when it follows eggs or sperm to the offspring. If a few of the offspring in a rearing unit acquire the disease, the virus will be released into the environment, initiating horizontal transmission with high mortality. Some of the larvae/fry, however, will survive, but may still harbor the virus, which could then be transmitted to the next generation. But, as the virus occurs at such high concentrations in the affected units, another possibility is that it can persist in the environment from one production batch of larvae to the next. As nodavirus is very stable and can survive in seawater for a long time (Frerichs et al. 2000), further research should concentrate on the measures that have to be implemented to eliminate the virus once it has entered a sea-farm.

Acknowledgements. This study was supported by the Research Council of Norway.

\section{LITERATURE CITED}

Arimoto M, Mushiake K, Mizuta Y, Nakai T, Muroga K, Furusawa I (1992) Detection of striped jack nervous necrosis virus (SJNNV) by enzyme-linked immunosorbent assay (ELISA). Fish Pathol 27:191-195

Breuil B, Pepin JFP, Boscher S, Thiery R (2002) Experimental vertical transmission of nodavirus from broodfish to eggs and larvae of the sea bass, Dicentrarchus labrax (L.). J Fish Dis 25:697-702

Dannevig BH, Nilsen R, Modahl I, Jankowska M, Taksdal T, Press CMcL (2000) Isolation in cell culture of nodavirus from farmed Atlantic halibut Hippoglossus hippoglossus in Norway. Dis Aquat Org 43:183-189

Frerichs GN, Tweedie A, Starkey WG, Richards RH (2000) Temperature, $\mathrm{pH}$ and electrolyte sensitivity, and heat, UV and disinfectant inactivation of sea bass (Dicentrarchus

Editorial responsibility: Jo-Ann Leong,

Kaneohe, Hawaii, USA labrax) neuropathy nodavirus. Aquaculture 185:13-24

Grotmol S, Totland GK (2000) Surface disinfection of Atlantic halibut Hippoglossus hippoglossus eggs with ozonated sea-water inactivates nodavirus and increases survival of the larvae. Dis Aquat Org 39:89-96

Grotmol S, Totland GK, Thorud K, Hjeltnes BK (1997) Vacuolating encephalopathy and retinopathy associated with a nodavirus-like agent: a probable cause of mass mortality of cultured larval and juvenile Atlantic halibut Hippoglossus hippoglossus. Dis Aquat Org 29:85-97

Grotmol S, Bergh Ø, Totland GK (1999) Transmission of viral encephalopathy and retinopathy (VER) to yolk-sac larvae of the Atlantic halibut Hippoglossus hippoglossus: occurrence of nodavirus in various organs and a possible route of infection. Dis Aquat Org 36:95-106

Grotmol S, Nerland AH, Biering E, Totland GK, Nishizawa T (2000) Characterisation of the capsid protein gene from a nodavirus strain affecting the Atlantic halibut Hippoglossus hippoglossus and design of an optimal reversetranscriptase polymerase chain reaction (RT-PCR) detection assay. Dis Aquat Org 39:79-88

Johansen R, Grove S, Svendsen AK, Modahl I, Dannevig B (2004) A sequential study of pathological findings in Atlantic halibut, Hippoglossus hippoglossus (L.), throughout one year after an acute outbreak of viral encephalopathy and retinopathy. J Fish Dis 27:327

Munday BL, Nakai T (1997) Special topic review: nodaviruses as pathogens in larval and juvenile marine finfish. World $\mathrm{J}$ Microbiol Biotechnol 13:375-381

Munday BL, Kwang J, Moody N (2002) Betanodavirus infections of teleost fish: a review. J Fish Dis 25:127-142

Mushiake K, Nishizawa T, Nakai T, Furusawa I, Muroga K (1994) Control of VNN in striped jack: selection of spawners based on the detection of SJNNV gene by polymerase chain reaction (PCR). Fish Pathol 29:177-182

Reed LJ, Muench H (1938) A simple method of estimating fifty percent end points. Am J Hyg 27:493-497

Sambrook J, Fritsch EF, Maniatis T (1989) Molecular cloning, a laboratory manual. Cold Spring Harbor Laboratory Press, Cold Spring Harbor, NY

Skliris GP, Richard RH (1998) Assessment of the susceptibility of the brine shrimp Artemia salina and rotifer Brachionus plicatilis to experimental nodavirus infection. Aquaculture 169:133-141

Sommer AI, Amundsen Strand M, Rasmussen E, Mennen S (2004) Susceptibility of spotted wolffish Anarhichas minor to experimental infection with nodavirus and infectious pancreatic necrosis virus. Dis Aquat Org 59:101-108

Starkey WG, Millar RM, Jenkins ME, Ireland JH, Muir KF, Richards RH (2004) Detection of piscine nodavirus by realtime nucleic acid sequence based amplification (NASBA). Dis Aquat Org 59:93-100

Submitted: August 8, 2005; Accepted: October 16, 2006 Proofs received from author(s): December 8, 2006 